\title{
The Struggle of the Soviet Government against Famine and the Increase of the Homeless Children in the Akmola Governorate in 1921-1923
}

Gulmira Bolatovna Karsakova, ${ }^{+*}$ Zauresh Galimzhanovna Saktaganova, ${ }^{\top}$ Kadyrzhan Kabidenuly Abuev, $^{\dagger}$ Rosa Gafarovna Bukanova,' Zhanna Sabitbekovna Mazhitova ${ }^{\complement}$

\section{Abstract}

The article presents the consequences of the famine of 1921-1923, which affected many regions of the Kazakh Autonomous Soviet Socialist Republic (KASSR) and caused mass epidemics, having an impact on children. This article analyses, the activities of party-state bodies and children saving social organisations. Based on archival sources, the authors bring forward the data on the number of homeless children, both in the Republic and the regions. The article aims to cover the critical reasons for homelessness amongst children. In doing so, it includes not only the socio-economic factors but also the Soviet state's policy, which led to the destruction of families, famine, high mortality, etc. The findings conclude that child homelessness is a result of the difficult socioeconomic situation of the Republic, caused by war, famine and devastation.

Keywords: Child Homelessness, 1921-1923 Famine, Epidemic, Orphanage, Soviet Russia

\footnotetext{
${ }^{\dagger}$ Sh. Ualikhanov Kokshetau State University, Abay st.76, 020000, Kokshetau, Republic of Kazakhstan, Email: gulmirakarsakova@mail.ru

* Corresponding Author

${ }^{\bar{T}}$ Karaganda State University named after E.A. Buketov, Universitetskaya st.28, 100028, Karaganda, Republic of Kazakhstan

'Bashkir State University, Z. Validi st.32, 450000, Ufa, the Republic of Bashkortostan, Russia

I University of Astana, Abai st.13, 010000, Astana, Republic of Kazakhstan

(C)2018 Karsakova et al. This is an Open Access article distributed under the terms of the Creative Commons Attribution License (http://creativecommons.org/licenses/by/2.0), which permits unrestricted use, distribution, and reproduction in any medium, provided the original work is properly cited.
} 


\section{Introduction}

The critical rationale underlying this research can be argued by the absence of complete and objective analysis of the 1921-1922 famine problem in the history of Kazakhstan. The study of this topic on a scale of a single region allows a better understanding of the full range of natural and climatic, social-economic and political problems caused by famine on a national level, revealing the essential characteristics of the historical events, which took place in the extreme situation of 19211922.

The emergence and growth of homelessness are exacerbated by economic crises, unemployment, poverty and child exploitation, as well as the conflict family environment, immoral behaviour of parents, child abuse, wars, revolutions, famines, natural disasters, epidemics and upheavals that result in orphancy. Creation of the productive care system for homeless children is impossible without taking into account the distinct historical experience of child abandonment elimination in the 1920s. This experience remained unclaimed by society due to insufficient study. Thus, the development of this topic presents not only theoretical but also practical significance. Therefore, the activities of the state and public bodies concerning homeless children in the 1920s in Kazakhstan deserve a dedicated historical study.

The rationale of the present study is defined by the need to reconsider certain common perceptions in the scientific community on the performance results of the Soviet governing and public authorities regarding the homeless children in 1920, both nationwide and on a regional scale- in Akmolinsk governorate.

The problems associated with homeless children worsened in many countries in the early 20th century, especially after the World War I. However, they were dealt with in different ways. In Western Europe and the USA, the primary emphasis in the fight against homelessness was placed on family education and public charity. A similar approach could be observed in the pre-revolutionary Russia.
In Soviet Russia, the common forms of child protection were social upbringing and state custody of children. In contemporary Russia, the government still pays considerable attention to this subject. The struggle against homelessness here rapidly transformed from being a social phenomenon into being a political one. It was important for the Bolsheviks to not only liquidate the homelessness of 7 million children (in 1922) but to deal with it in such a way prioritising class values.

In the early 1920s, the entire territory of Akmola guberniya (governorate) became a zone of natural disaster, a social catastrophe. Typically, such affliction tends to bear upon the vulnerable social strata, and the child is the most susceptible stratum of all.

Considering the term 'homeless children', in the period from 1917 to 1926 it had no precise definition, thus leaving its interpretation to be vague and obscure. The infrequent discussions on this topic did not solve the issue (Gernet 1924; Kufayev 1925; Livshits 1925; Lunacharskiy 1987). Therefore, according to $Y$. Livshits, a homeless child- 'is one put in such conditions, in which they provide for themselves, and sometimes even for their loved ones as well. It does not matter whether such a child has a bed to sleep on or lives in a 'family' (Livshits 1925, p. 15).

P.I. Lyublinskiy identified various types of homelessness depending on the factor causing it, that is, orphancy; penury, abandonment and defenselessness. In this regard, the author compared homelessness to a long-lasting ailment, which comes through several stages or phases of its progression. He found the initial stage of this social disease to be the neglect, and the final, advanced case was homelessness itself, which defines the social status of a minor, either chosen voluntarily or gained due to some other circumstances. He considered children's defenselessness to be an essential factor causing homelessness (Lyubinskiy 1923, p. 7).

V.I.Kufaev defined homelessness as a status, applicable to children without parents and not 
in the care of institutions or any other individuals, that is, lacking care and economic security (Kufayev 1925, p. 132).

Therefore, the understanding of homelessness was mainly seen in connection with the child's personality and the conditions he or she was in. Only after the release of the Decree of the AllRussian Central Executive Committee and the Council of People's Commissars of the RSFSR on 8 March 1926, the concept of 'homeless children' was defined (Boldyrev 1947, p. 233238). This document classified children into the homeless', and those requiring 'temporary or partial assistance and mentoring' (Boldyrev 1947). Only children under 16 , 'who did not have parents, adult brothers, sisters, capable of taking care of them; who lost contact with parents and relatives; who were deprived of the family by court order or by a commission on juvenile affairs; exposed children' began to be considered as homeless children (Boldyrev 1947, p. 300).

Therefore, starting from the second half of the 1920s, child homelessness was defined as the absence of a permanent place of residence, specific occupations, family or state care, and systematic educational influence among children and adolescents resulted from the loss of parents, leaving the family, dropping out of an educational institution (Sazhina 2003, p. 36). The article begins with a description of methodological issues followed by the discussion of findings.

\section{Methodological Issues}

The research employed various methodological approaches as its methods, united by universal principles of scientific objectivity, systematic consistency, and historicism. These allowed analysing the problem of child homelessness, considering events and phenomena of the past as an element of a unified system, and studying those events in the development process in the frame of a specific historical situation.

It is important to accentuate analysis and synthesis among general scientific methods of cognition used in the writing of the work. The analytical method assisted in revealing the specifics of the activities of the government bodies and public organisations in Akmola province, while the synthetic method indicated their place in the system of social development in the KASSR. The study of archival material determined the application of the comparativehistorical method making possible the analysis of the interrelated implementation mechanisms of various child abandonment countermeasures. The chronological method allowed analysing and arranging events in a strict time sequence. The descriptive approach is based on involving a wide range of sources to demonstrate certain phenomena or processes.

\section{Discussion}

From our point of view, the main reasons for the appearance of homeless children in the early 1920s were the World War I, the 1917 Revolution, the Civil War, during which the Bolsheviks established a surplus-appropriation system. Consequently, it had a negative impact on the economic activities of the Russian peasants and Kazakh nomadic cattlemen. Millions of those murdered during these years in wars, famine and epidemics, devastated during the unsuccessful experiments of Soviet power, untimely left their children orphaned. The further life of these children in critical times was tragic. The colossal mortality of the adult population provoked the homelessness of children and the juvenile delinquency that ensued.

The total famine of the early 1920's triggered an unprecedented rate of homelessness with its direct consequences - juvenile crime, prostitution, begging and various mental disorders among children and adolescents trying to survive. According to the Chairman of the Central Executive Committee of the USSR, M.I. Kalinin in 1923 in the Soviet state there were more than 5.5 million homeless, neglected and abandoned children (Topolyanskiy 2008).

The large-scale famine occurred in the Akmola uyezd (administrative division similar to a county), which had a reputation of the most fertile province in Akmolinsk governorate. The policy of 'war communism', poor harvest and 
steppe murrain in 1922 significantly contributed to the appearance in the county of 'the ghost of land along the Volga' (Central State Archive of the Republic of Kazakhstan, F. 82. L. 1. C. 212 , p. 69). Starving people, in particular, residents of the southern districts Asan-Kaygi and Sary-Arka, headed to the city of Akmolinsk, where they tried to find employment and improve their distressful situation. Orphanages were full of homeless children. The people had to eat cats, dogs, and ersatz food (Central State Archive of the Republic of Kazakhstan, F. 82. L. 1. C. 52, p. 12).

The homeless children became the symbol of that time. As early as 1921, articles and notes on homeless children began to appear in the Soviet press. As a result, in the summer of 1922, a report of the Workers' and Peasants' Inspectorate on child homelessness and juvenile delinquency was published in 'Izvestiya' newspaper (before the publication such information had been available only to a limited circle of country leaders). Since 1923, some serious reading on homelessness began to appear (Rozhkov 2000, p. 135).

The increase in the number of starving people led to the growth of child homelessness. For example, on 1 December 1921, there were 128000 homeless children in the KASSR; on 31 December - 158000 children, and in January 1922, this number increased to 333043 (State Archives of the Russian Federation, F. 1058. L. 1. C. 175, p. 1$)$.

In August 1921, the Presidium of the Kazakh Central Executive Committee addressed the issue of children and youth in the governorates of the republic. In the report by the Presidium member A. Aitiev, it was stated that there were '132 orphanages with 44698 children recorded that in the starving governorates. There was an acute lack of clothing, food, shoes, and utensils. The burden of disease among children was great: dysentery, typhoid, cholera' (Central State Archive of the Republic of Kazakhstan, F. 5. L. 2. C. 17, p. 71).

The Central Committee of the famine relief reported that 'as of June 1922, 777192 people were provided with food, 422799 of which being children'. As of 1922, the Committee to fight against the famine aftermath in Kazakhstan found '219328 homeless children, who were to be helped using a special program, developed with the allocation of material resources. In five governorates, 575 orphanages and nine children's reception centres were opened' (Central State Archive of the Republic of Kazakhstan, F. 5. L. 2. C. 17, p. 363).

In 1922, there were 14 orphanages in Akmolinsk governorate for 9426 children and four shelters for infants under 3 years old. According to the sources, 'infant mortality was high and reached 40\%' (State Archives of the Akmolinsk Region, F.115. L.1. C. 5, p. 42). In 1922, there were 300 children for feeding among the population of Petropavlovsk. This was expressed by the fact that the orphanages were liquidated due to lack of funds. The children were redistributed among the population of the parish '1-2 people per each labor establishment of 1000 people. The numbers of children were as follows: Petropavlovsk - 1396, Kokchetav - 450, Atbasar - 300, Cherlak - 150 people. The total number is 2596 children' (Central State Archive of the Republic of Kazakhstan, F. 1215. L. 1. C. 19 , p. 54).

Due to the 'undernourishment' (bad harvest due to drought) in most of the governorates of the KASSR, the first place amongst which belonged to Uralsk and Aktyubinsk governorates, two counties of Akmolinsk governorate and partially Orenburg governorate, the children's homelessness of cities increased significantly because of the influx of children from the villages. Hence, for example, 'in Akmolinsk governorate the number of homeless children out care of orphanages amounted to 2963 people' (Central State Archive of the Republic of Kazakhstan, F. 1215. L. 1. C. 19, p. 9).

Since 1920, the Department for Juvenile Welfare in the sector of social education of the People's Commissariat of Education (originated from the Department of Orphanages under the People's Commissariat of Social Welfare) was 
obligated to fight against homelessness, create orphanages, legally protect children, and support homeless people. Following the Decree by the People's Commissariat of Education of the RSFSR on 11 February 1921, the General Directorate of Social Education and Polytechnic Education for children under 15 was established. At the same time, the Commission for the improvement of the life of children was established on 27 January 1921 under the initiative of the People's Commissar for Internal Affairs F. E. Dzerzhinsky and approved by the Decree of the Presidium of the All-Russian Central Executive Committee on 10 February 1921 (Lunacharskiy 1987, p. 266). During the first half of the 1920s, the administrative means were developing, and the system for homeless child support was improved. In April 1922, the Department of Social and Legal Protection of Minors and the Education of the Defective was established under the Main Directorate of Social Education. The Department ordered to conduct a nationwide survey of child institutions, which again confirmed that at the moment, the primary task was neither to improve the lives of children nor to provide them with any additional benefits, but to 'save the younger generation from extinction' (State Archives of the Russian Federation, F. R-5207. L. 1. C. 48, p. 20).

The homelessness control system included the identification and support of street children, disadvantaged families, social assistance, and the prevention of homelessness. Juvenile educational institutions of boarding type were established, that is, orphanages, labour communes, colony schools, commune schools, 'children's villages' (several joined children's homes, schools, School of Factory Trade apprenticeship with their infrastructure and auxiliary institutions) and others (Izvestiya of Central Executive Committee of the USSR and All-Russian Central Executive Committee, 1926, 14 February).

The Kazakh Central Executive Committee petitioned the Central Commission for Combating Harvesting Hazards to provide funds 'in the amount of 472584 rubles for food and the organization of primary institutions for street children - feeding stations or canteens during seven months of winter' (State Archives of the Russian Federation, F. 7820. L. 1. C. 16, p. 57). Thus, in Petropavlovsk on 8 November 1923, the meeting of the Akmolinsk Governorate Commission decided: ' 8000 poods of rye (a unit of weight of the Imperial Russian weight measurement system; one pood equals approximately 16.38 kilograms) should be distributed as follows: 1000 poods granted to the Akmolinsk Governorate Children's Commission to help street children, granting the Akmola Commission the right to distribute this amount of rye in the governorate, strictly according to the actual need on the ground. 7000 poods were distributed as follows: 1) $60 \%$ that is, 4200 poods for the following uyezds (counties): Kokchetav - 1500, Atbasar - 1000, Akmola - 1250, Cherlak - 450; 2) 200 poods for the Governorate Council for the support of homeless famine victims' (Central State Archive of the Republic of Kazakhstan, F. 1215. L. 1. C. 19, p. 90).

To combat child homelessness and hunger, it was planned to open feeding stations. The network of feeding stations was to be spread over the volost centres, designed to serve 50 people per point. The total number of children in need of food assistance in rural areas reached 'up to 12668 people, which are distributed according to the governorates as follows: Aktobe - 5564, Bukeyevsk - 2158, Akmola - 1013, Ural - 1122, Pavlodar - 1075, Atbasar county - 593 people' (State Archives of the Russian Federation, F. 7820. L. 1. C. 16, p. 66). The feeding stations were supposed to give the children hot food once a day.

The central institutions for street children and adolescents were reception centres and children's homes of various types (that is, there were about 23 different names for orphanages). In the beginning, the scheme to combat homelessness was simple: a child from the street - a children's reception point - an orphanage. This order very soon led to the overflow of orphanages, which the state was 
no longer able to support. With the transfer in 1923 of children's institutions to the local budget, the number of orphanages and children in them began to decline sharply (State Archives of the Russian Federation, F. 5443. L. 26. C. 24, p. 50$)$.

It was irony to note that most homeless children even failed to survive in the children's homes. In archival sources it is recorded: 'At present, due to the natural famine that has overtaken Kirrespublik (the Kazakh Republic. authors), the mortality of children under 1 year of age in our homes varies between $80-90 \%$, and over one year of age - between $50-60 \%$. Due to the overload and lack of conveniences, the sanitary condition of orphanages is below criticism: mud, stench, crowding; three or four children per bed if beds are present; no mattresses or blankets; no light; children are dirty, naked, barefoot, spending the entire days waiting for a half-starved dinner. Children emaciated physically and became morally dull' (Central State Archive of the Republic of Kazakhstan, F. 82. L. 1. C. 104, p. 37).

Children's homes lacked bed linen, clothes, and shoes. Typhoid, cholera, dysentery, scabies carried away many lives. However, more than from illness, children died from exhaustion. For example, in November-December 1921, 115 children died. As evidenced by the materials of the Juvenile Committee, by 1921 the 'feeding of children' was not established 'positively anywhere'. The report of the Juvenile Committee revealed the Presidium of the AllRussian Central Executive Committee on 15 April 1921 that 'children are half-starved, occasionally eating only cabbage and bread or frozen potatoes' (State Archives of the Russian Federation, F. R-5207. L. 1. C. 8, p. 19). There was no exact information about the number of starving children in the Republic and individual governorates. This circumstance made it impossible to maintain a scheduled supply of the governorates with food rations for children. Therefore, the Children's Commission firstly tried to establish the number of children in various regions to organise the supply of their rations according to a specially developed standard. The daily norms were not uniform for the whole republic at first, but they were determined depending on local conditions. On average, every student of a closed children's institution in the country was provided with '200-300 grams of bread a day, about 100 grams of meat or fish and the same amount of cereals, $300-400 \mathrm{~g}$ of potatoes, 12 grams of salt and sugar. In some governorates, the food standard also included eggs (20 per month), milk (a glass a day), and vegetables (about 200 grams)' (State Archives of the Russian Federation, F. R-5207. -L. 1. C. 8, p. 209). The telegram of Gubernial Executive Committee characterised the situation with the food of children to KazCEC (Kazakh Central Executive Committee): 'Kirghiz People's Commissariat for Food allowed only 500 rations for children's homes, instead of the former 6710. There are nearly ten thousand children, the situation is terrible, some of them happens to be thrown out on the street. Take urgent measures' (Central State Archive of the Republic of Kazakhstan, F. 1215. L. 1. C. 19, p. 10). Some orphanages did not receive food for months, which made the children fled to avoid starving.

In total, over 2300 thousand people were starving, about 1 million people died of hunger and disease. It should be considered that this information is incomplete because the registration of the starving in Kazakhstan began only since November 1921. So, comparing the November 1921 figure in Kazakhstan, with the data retrieved from the People's Commissariat of Health, '1559911 people were starving or there were 315 starving people per 1000 people, in April 1922, the number of the starving people reached 2471740' (Central State Archive of the Republic of Kazakhstan, F. 82. L. 1. C. 212 , p. 22).

Archival materials show a terrible picture of the growing number of the starving in Kazakhstan. At the same time, it would be wrong to suggest that the state did not take measures to combat hunger and homelessness at this challenging time. Thus, the Central Children's Commission gave an order to the governorate commissions in early November 1921. According to that 
order, the child orphanages were not to be closed, despite overcrowding, and would continue to receive children. The Commission was invited to immediately begin the opening of special reception homes for street children in which they could get shelter, food, and care. Moreover, the central children's commission raised the issue of saving children making it 'a matter of the day', urging all authorities and the population to support homeless children in every possible way. It should be emphasised that the appeals of the commission did not remain unheard. The establishment of the shelters and care facilities for children developed at a rapid pace, and the establishment of new orphanages of normal (regular) type did not fall behind. Comparing the number of children in institutions from 1 July 1921 to September 1922, it can be observed that the numbers increased over the given period. 'Given that on 1 July 1921, there were 423 children's institutions with 21551 children in schools, and on 1 January 1922 580 institutions with 33342 children; in contrast, on 1 July 1922, the number decreased to amount to 505; however, the number of children increased to account for 41215 . On 1 September 1922, the number of institutions was 498 with 33726 children' (State Archives of the Russian Federation F. 1065. L. 2. C. 113, p. 85).

Famine had a direct connection with the negative child homelessness trend in the Republic between 1921 and 1922. Table 1 presents the dynamics of the population of homeless children in KASSR and Akmola governorate in 1921-1922, while Table 2 paints the number of children's institutions in KASSR and children in them as of on September 1922.

\section{Table 1: The Number of Homeless Children in KASSR and Akmola Governorate in 1921-1922}

\begin{tabular}{lllll} 
Name of the republic and & November & December & January & March \\
governorate & 1921 & 1921 & 1922 & 1922 \\
\hline KASSR & 100000 & 128873 & 158564 & 408022 \\
\hline Akmolinsk governorate & 8176 & 8670 & 13170 & 12000 \\
\hline
\end{tabular}

Source: State Archives of the Russian Federation, F. 1066. L. 2. C. 20, p. 230

Table 2: Number of children's institutions in KASSR and children in them as of on September 1922

\begin{tabular}{|c|c|c|c|c|c|c|}
\hline \multirow{2}{*}{ Name of the governorate } & \multicolumn{3}{|c|}{ Orphan asylum } & \multicolumn{3}{|c|}{ Children's rooms } \\
\hline & $\begin{array}{l}\text { Orphan } \\
\text { asylums }\end{array}$ & $\begin{array}{l}\text { Number } \\
\text { children }\end{array}$ & of & Rooms & $\begin{array}{l}\text { Number } \\
\text { children }\end{array}$ & of \\
\hline Orenburg & 120 & 6582 & & 12 & 1890 & \\
\hline Uralsk & 65 & 3673 & & 7 & 1400 & \\
\hline Aktubinsk & 100 & 6583 & & 7 & 1550 & \\
\hline Kustanai & 53 & 2909 & & 5 & 1050 & \\
\hline Bukeyevsk & 13 & 588 & & 3 & 500 & \\
\hline Akmolinsk & 35 & 1790 & & 7 & 1550 & \\
\hline Semipalatinsk & 49 & 2562 & & 4 & 650 & \\
\hline Adayevsk uyezd & 8 & 449 & & - & - & \\
\hline Total & 453 & 25136 & & 45 & 8590 & \\
\hline
\end{tabular}

Source: State Archives of the Russian Federation, F. 1065. L. 2. C. 116, p. 6

Notwithstanding, with the efforts of children, there were wheat and other cereals that were produced on the areas of land available for children communes. Children communes became nearly the only institution to provide real support to the homeless minors in the Republic. The main contingent of street children in the KASSR was children of peasants and workers. The primary task of the Soviet government in the fight against child 
homelessness was to re-establish the proletarian status of those children, which prompted the establishment of workshops: shoemakers, carpenters, tailors and others. There were 35 different workshops in the KASS, turned into an auxiliary body for servicing the needs of orphanages, for example, such as sewing and repairing linens and shoes, bookbinding, etc. To develop the skills of adolescents in orphanages and homeless children, the state authorities established main workshops where teenagers could study a craft professionally under the guidance of an experienced mentor, working for several shifts.

\section{Conclusion}

To conclude, it should be said that the Soviet government had put in a massive effort to include the street children into normal social life by organising their physical labour and distributing them amongst families. Considering the results of the care for homeless children in 1921-1923, it is necessary to take into account the difficult situation in which the Republic was at that time. It was not possible to eliminate homelessness and radically improve the position of the children population, but positive steps were undertaken in the country taking into account the economic situation. Supported by the central government, the local authorities made tremendous efforts to save children from famine and epidemics. Various children's institutions were created, offering children a wide range of services - from housing to temporary employment. At the same time, the Soviet authorities failed to solve the problem of eliminating homelessness and famine partly because of the uncertain economic circumstances in the Republic. The measures were taken, but they were not enough to entirely solve the problem.

\section{References}

Boldyrev, N. I. (1947). The directives of the AllUnion Communist Party of the Bolsheviks (VKPB) and the decisions of the Soviet Government on public education: Sourcebook for 1917-1947 period. Moscow-Leningrad: Izd-vo Akad. PED. Sciences of the RSFSR, pp. 320.
Central State Archive of the Republic of Kazakhstan (CSA RK). F. 1215. L. 1. C. 19, pp. 9-90.

Central State Archive of the Republic of Kazakhstan (CSA RK). F. 5. L. 2. C. 17, pp. 71-363.

Central State Archive of the Republic of Kazakhstan (CSA RK). F. 82. L. 1. C. 104, p. 37.

Central State Archive of the Republic of Kazakhstan (CSA RK). F. 82. L. 1. C. 212, pp. 7-69.

Central State Archive of the Republic of Kazakhstan (CSA RK). F. 82. L. 1. C. 52, pp. 527.

Central State Archive of the Republic of Kazakhstan (CSA RK). F.82. L. 1. C. 280, pp. 7-21.

Gernet M. N. (1924). Socia-legal protection of childhood abroad and in Russia. Moscow: Law and Life, pp. 68.

Izvestiya of Central Executive Committee of the USSR and All-Russian Central Executive Committee. (1926, 14 February). Available at: http//www.codex.barrt.ru/ (accessed April 01, 2018)

Kufayev V. I. (1925). Young Offenders. Moscow: New Moscow, pp. 350.

Livshits Y. (1925). The social roots of homelessness. Moscow: Rabotnik prosvesheniya, pp. 207.

Lunacharskiy A. V. (1987). Dzerzhinskiy in People's Commissariat of Education. Moscow: Gospolitizdat, p. 266.

Lyubinskiy P. I. (1923). Combating crime in childhood and adolescence: socio-legal essays. Moscow: Legal publishing house of the People's Commissariat of Justice, pp. 302.

Rozhkov A. Yu. (2000). Struggle against homelessness in the first Soviet decade. History questions, 11, pp. 134-139.

Sazhina N. S. (2003). The activities of the state and public organizations to eliminate child 
homelessness in 1921-1928: on the sources of the Urals: PhD diss. Russian State Vocational and Pedagogical University, Moscow, pp. 174.

State Archives of the Akmolinsk Region. F.115. L.1. C. 5, pp. 42.

State Archives of the Russian Federation (SA RF). F. 1065. L. 2. C. 113, pp. 13-90.

State Archives of the Russian Federation (SA RF). F. 1066. L. 2. C. 20, pp. 230-251.

State Archives of the Russian Federation (SA RF). F. 1058. L. 1. C. 175, pp. 1-12.

State Archives of the Russian Federation (SA RF). F. 1065. L. 2. C. 116, p. 5 back of the page -6 .
State Archives of the Russian Federation (SA RF). F. 5443. L. 26. C. 24, p. 50.

State Archives of the Russian Federation (SA RF). F. 7820. L. 1. C. 16, p. 16 back of the page, 66 back of the page.

State Archives of the Russian Federation (SA RF). F. R-5207. L. 1. C. 48, p. 209.

State Archives of the Russian Federation (SA RF). F. R-5207. -L. 1. C. 8., p. 19-20.

Topolyanskiy V. (2008). Report on the famine of 1921 - 1922. New newspaper, 45. Available at: http://

www.novayagazeta.ru/data/2008/color45/2

5.html (accessed April 01, 2018) 